الترقيم الدولي • 1991 - 199

website: http://jsci.utq.edu.iq
Email: utjsci@utq.edu.iq

\title{
Determination of the authority of age and sex in some biochemical parameters of patients with diabetes in Thi-Qar Governorate-Iraq
}

\section{Baida Rehan Ali Al-Musawii \\ University of Thi-qar - College of Science - Department of Biology}

\begin{abstract}
$\underline{\text { Abstract }}$
The present study was designed to evaluate the effect of age and sex in diabetic patients on serum blood biochemical parameters. In this study, a total number of 165 diabetic patients from patients visiting Al-Hussein teaching hospital in Al-Nassiriya city were involved and according to age and sex were classified into 87 male vs. 78 female; precent $(52,72 \%)$ male and precent $(47,27 \%)$ female respectively. From each patient, serum blood samples were collected for estimate various blood parameters.

The results of the current study demonstrated that cholesterol, triglycerides, and VLDL were significantly higher in males $(\mathrm{P}<0.05)$ as compared to female patients. Regarding the total serum cholesterol there was no significant $(\mathrm{P}>0.05)$ difference, while serum triglyceride was significantly higher in age group of $(30-39)$ year and $(40-49)$ year $(\mathrm{P}<0.001)$ compared to group (20-29) year, but the difference was statistically not significant $(\mathrm{P}>0.05)$. It was concluded that the age and sex in both diabetic men and women affect directly on biochemical blood parameters.
\end{abstract}




\section{Introduction}

Diabetes mellitus (DM) is one of the most widely distributed metabolic disorders which may affect almost all populations of the world at a variable prevalence. However, it is characterized by chronic hyperglycemia with disturbances. DM is associated with abnormal changes in protein, carbohydrate, fat metabolism, and induce the disturbances in lipid profiles especially, an increased susceptibility to lipid per oxidation. Type II diabetes accounts for $90 \%$ to $95 \%$ of all patients with diabetes and is increasing in prevalence, especially in minority populations.

Diabetes mellitus (DM) is currently taking its place as one of the main threats and hazard to human health in the 21 st century. In the past two decades the number of people with diabetes has increased worldwide. However, DM affects approximately $6 \%$ of the world population (1). In some studies DM was 151 million and the number is projected to increase by $46 \%$ to reach 221 million by the year 2010 and 300 million in 2025 (2). DM is a heterogeneous group of disorders characterized by high blood glucose level (3). It is associated with abnormal changes in protein, carbohydrate and fat metabolism (4), and induce disturbances in lipid profiles especially, an increased susceptibility to the lipid peroxidation. (Type II ) diabetes accounts for $90 \%$ to $95 \%$ of all patients with diabetes and is increasing in prevalence, especially in minority populations (5).

It usually begins in middle life or later (6). The two primary pathogenic factors leading to type II diabetes are insulin resistance and decreased insulin secretion, which arise from abnormalities within the liver, fatty tissue skeletal muscle, and pancreatic $\beta$ cells (7). Narayan et al. (8) demonstrate that there are a strong relationship between DM and disturbances of lipoprotein metabolism that the most widely used classification of lipoproteins is based on their different densities, which determine their behavior during preparative equilibrium ultracentrifugation as follows, Chylomicron (Dietary triglycerides as a major lipid), Very low density lipoprotein (VLDL) (Endogenous triglycerides), Low density lipoprotein (LDL) (cholesteryl esters). In addition to, the death may result from acute metabolic decompansation while long standing metabolic derangement is frequently associated with permanent and irreversible functional and structural damage in the cells of the body, with those of the vascular system being particularly susceptible (9). Moreover, it may result from acute metabolic decompansation while long standing metabolic derangement is frequently associated with permanent and irreversible functional and structural damage in the cells of the body, with those of the vascular system being particularly susceptible (10).

\section{Subjects, Materials and Methods}

One hundred sixty-five fasting blood samples were obtained from 87 male and 78 female patients with diabetes and investigated in the diabetic center of Al-Nassiriya city/Iraq. The age of patients was between 20- 60 years or more whom divided in to (2029) years, (30-39) years, (40-49) years, (50-59) years, and (>60) years. Fasting blood samples were obtained from all patients and control group included in this study by antecubital vein puncture, between 9-11 a.m, about $(7 \mathrm{ml})$ of blood was obtained after 12 hrs fasting. The blood discharge into disposable plain tube, left for 15-30 minutes at 37 ${ }^{\circ} \mathrm{C}$ for clot formation in water bath, then serum was separated by centrifugation at 3000 $\mathrm{rpm}$ for $10 \mathrm{~min}$, and the sera were frozen at $-20{ }^{\circ} \mathrm{C}$ and kept for analysis at weekly patches. Sera were used for enzymatic spectrophotometric estimation of the following biochemical parameters 


\section{Serum Triglycerides Concentration}

Serum triglycerides concentration is measured by enzymatic calorimetric method which is available as a kit (Biocon-Germany)

\section{Total Serum Cholesterol Concentration}

Total serum cholesterol was measured in the serum by enzymatic calorimetric method which is available as a kit of (Biocon-Germany).

\section{Serum Creatinine}

Creatinine reacts with picric acid in alkaline conditions to form a salt of yellow-red color. The rate of formation of color is proportional to the creatine concentration in the sample.

\section{Blood Urea}

Enzymatic determination of urea accordinting to the following reaction: -

$$
\mathrm{Urea} \stackrel{+\mathrm{H2O}}{\longrightarrow}+2 \mathrm{H}+\text { urease } 2 \mathrm{NH}^{++} \mathrm{CO}_{2}
$$

The ammonium ions formed react with salicylate and hypochloride to give agreen dye (2.2 Dicarboxylindophenol); intensity of the green color measured by spectrophotometer reflects the concentration of urea in the sample.

\section{$\underline{\text { Results }}$}

The results of the present study demonstrate that the frequency and distribution for diabetic human bing for all blood parameters and in all age groups have markedly decline decrease with advance age, except creatinine parameters shows initially decrease in age group (20-29 years) and cholesterol parameters shows increase with progress in age groups ( $\geq 60$ years), while VLDL begins in value reject also in age group ( $\geq 60$ years) as shown in table (1). However, the incidence and delivery for diabetic men especially in creatinine and VLDL values indicated that the male and female age groups (30-39) years and (40-49) years have the largest numbers of diabetic human bing as compared to other age groups have better results than others groups (Table 1 and 2; respectively). The results of PB for different male and female age groups of diabetic human bing are presented in the table (1, 2 ;). It was noticed that the sugar and urease in male and female, and triglyceride in male have non significant $(\mathrm{P}>0.05)$ in all male age groups (Table 3). While, Creatinine parameters for male patients give highly significant $(\mathrm{P}<0.001)$ correlation (Table 3$)$. 
Table (1): Blood parameters for diabetic patients ${ }^{*}$ classified according to male age groups

\begin{tabular}{|c|c|c|c|c|c|}
\hline \multirow[b]{2}{*}{ Parameters } & \multicolumn{5}{|c|}{ Male age groups (years) } \\
\hline & $\begin{array}{c}20-29 \\
\text { years } \\
(\mathrm{No}=8)\end{array}$ & $\begin{array}{c}\text { 30-39 years } \\
(\text { No. }=20)\end{array}$ & $\begin{array}{c}40-49 \text { years } \\
(\mathrm{No}=26)\end{array}$ & $\begin{array}{c}50-59 \text { years } \\
(\mathrm{No}=18)\end{array}$ & $\begin{array}{c}\geq 60 \text { years } \\
(\mathrm{No}=15)\end{array}$ \\
\hline $\begin{array}{l}\text { B. Sugar } \\
(\mathrm{mmol} / \mathrm{L})\end{array}$ & $15.30 \pm 1.85$ & $11.14 \pm 0.96$ & $10.84 \pm 0.82$ & $9.73 \pm 1.05$ & $10.86 \pm 1.09$ \\
\hline $\begin{array}{c}\text { B.Urea } \\
(\mathbf{m m o l} / \mathrm{L})\end{array}$ & $6.43 \pm 0.15$ & $6.34 \pm 0.15$ & $6.25 \pm 0.15$ & $6.29 \pm 0.23$ & $6.36 \pm 0.12$ \\
\hline $\begin{array}{c}\text { S.Creatinine } \\
(\mathrm{mmol} / \mathrm{L})\end{array}$ & $68.00 \pm 1.77$ & $76.20 \pm 2.13$ & $75.23 \pm 1.66$ & $76.00 \pm 2.17$ & $76.26 \pm 2.58$ \\
\hline $\begin{array}{l}\text { S.Cholesterol } \\
(\mathrm{mmol} / \mathrm{L})\end{array}$ & $4.73 \pm 0.12$ & $4.88 \pm 0.21$ & $4.95 \pm 0.20$ & $4.22 \pm 0.17$ & $5.12 \pm 0.30$ \\
\hline $\begin{array}{c}\text { S.Triglyceride } \\
(\mathrm{mmol} / \mathrm{L})\end{array}$ & $2.23 \pm 0.10$ & $2.16 \pm 0.06$ & $2.31 \pm 0.13$ & $2.13 \pm 0.06$ & $2.23 \pm 0.09$ \\
\hline $\begin{array}{l}\text { S.VLDL } \\
(\mathrm{mmol} / \mathrm{L})\end{array}$ & $0.92 \pm 0.03$ & $0.92 \pm 0.03$ & $0.92 \pm 0.03$ & $0.88 \pm 0.03$ & $0.98 \pm 0.04$ \\
\hline
\end{tabular}

Values are Mean \pm S.E.M

Total No. of diabetic men $=87$

*Mean of age for diabetic men (31.35 \pm 0.66 years)

Table(2):Blood parameters for diabetic patients ${ }^{*}$ classified according to female age groups

\begin{tabular}{||c||c||c|c||c||c||}
\hline \multicolumn{1}{||c||}{} & \multicolumn{5}{c||}{ Female age groups (years) } \\
\cline { 2 - 6 } Parameters & $\begin{array}{c}20-29 \text { years } \\
(\mathrm{No}=11)\end{array}$ & $\begin{array}{c}30-39 \text { years } \\
(\mathrm{No}=21)\end{array}$ & $\begin{array}{c}40-49 \text { years } \\
(\mathrm{No}=21)\end{array}$ & $\begin{array}{c}50-59 \text { years } \\
(\mathrm{No}=12)\end{array}$ & $\begin{array}{c}\geq 60 \text { years } \\
(\mathrm{No}=13)\end{array}$ \\
\hline $\begin{array}{c}\text { B. Sugar } \\
(\mathrm{mmol} / \mathrm{L})\end{array}$ & $10.20 \pm 1.15$ & $11.08 \pm 0.18$ & $13.05 \pm 1.05$ & $12.42 \pm 1.14$ & $11.28 \pm 1.09$ \\
\hline $\begin{array}{c}\text { B.Urea } \\
(\mathrm{mmol} / \mathrm{L})\end{array}$ & $6.03 \pm 0.16$ & $6.28 \pm 0.13$ & $6.42 \pm 0.15$ & $6.33 \pm 0.19$ & $6.08 \pm 0.16$ \\
\hline $\begin{array}{c}\text { S.Creatinine } \\
(\mathrm{mmol} / \mathrm{L})\end{array}$ & $76.00 \pm 2.60$ & $75.23 \pm 1.90$ & $77.33 \pm 2.05$ & $74.86 \pm 2.66$ & $75.69 \pm 2.83$ \\
\hline $\begin{array}{c}\text { S.Cholesterol } \\
(\mathrm{mmol} / \mathrm{L})\end{array}$ & $5.10 \pm 0.24$ & $4.97 \pm 0.25$ & $5.32 \pm 0.20$ & $5.06 \pm 0.23$ & $4.67 \pm 0.27$ \\
\hline $\begin{array}{c}\text { S.Triglyceride } \\
(\mathrm{mmol} / \mathrm{L})\end{array}$ & $2.20 \pm 0.05$ & $1.97 \pm 0.12$ & $2.22 \pm 0.09$ & $2.19 \pm 0.08$ & $2.13 \pm 0.09$ \\
\hline $\begin{array}{c}\text { S.VLDL } \\
(\mathrm{mmol} / \mathrm{L})\end{array}$ & $0.93 \pm 0.02$ & $0.91 \pm 0.03$ & $0.94 \pm 0.04$ & $0.95 \pm 0.03$ & $0.89 \pm 0.04$ \\
\hline \hline
\end{tabular}

Values are Mean \pm S.E.M

Total No. of diabetic female $=78$

* Mean of age for diabetic female $(30.83 \pm 0.89$ years $)$ 
Table (3): blood parameters for two male ${ }^{*}$ and female ${ }^{* *}$ diabetic patients according to staticticallv sionificant correlation

\begin{tabular}{|c|c|c|c|c|c|c|}
\hline \multirow{3}{*}{ Parameters } & \multicolumn{6}{|c|}{ Significant levels between two groups (P-value) } \\
\hline & \multirow{2}{*}{$\begin{array}{l}20-29 \\
\text { years } \\
\text { male }\end{array}$} & \multirow{2}{*}{$\begin{array}{c}\text { 20-29 years } \\
\text { Female }\end{array}$} & \multirow{2}{*}{$\begin{array}{c}\text { 30-39 years } \\
\text { Male }\end{array}$} & \multirow{2}{*}{$\begin{array}{c}\text { 30-39 years } \\
\text { Female }\end{array}$} & \multicolumn{2}{|c|}{ P-value } \\
\hline & & & & & male & Female \\
\hline $\begin{array}{l}\text { B. Sugar } \\
\text { (mmol/L) }\end{array}$ & $\begin{array}{c}15.30 \pm 1.85 \\
\mathrm{a} \\
\end{array}$ & $\begin{array}{c}10.20 \pm 1.15 \\
\mathrm{~A} \\
\end{array}$ & $\begin{array}{c}10.84 \pm 0.82 \\
a \\
\end{array}$ & $\begin{array}{c}11.08 \pm 0.18 \\
\mathrm{~A} \\
\end{array}$ & $\mathrm{NS}^{*}$ & $\mathrm{NS}^{*}$ \\
\hline $\begin{array}{c}\text { B.Urea } \\
(\mathrm{mmol} / \mathbf{L})\end{array}$ & $\begin{array}{c}6.43 \pm 0.15 \\
\text { a }\end{array}$ & $\begin{array}{c}6.03 \pm 0.16 \\
\mathrm{~A}\end{array}$ & $\begin{array}{c}6.25 \pm 0.15 \\
a\end{array}$ & $\begin{array}{c}6.28 \pm 0.13 \\
\mathrm{~A}\end{array}$ & $\mathrm{NS}^{*}$ & $\mathrm{NS}^{*}$ \\
\hline $\begin{array}{c}\text { S.Creatinine } \\
(\mathrm{mmol} / \mathrm{L})\end{array}$ & $\begin{array}{c}68.00 \pm 1.77 \\
b\end{array}$ & $\begin{array}{c}76.00 \pm 2.60 \\
C\end{array}$ & $\begin{array}{c}75.23 \pm 1.66 \\
\mathbf{b}\end{array}$ & $\begin{array}{c}75.23 \pm 1.90 \\
\mathrm{C}\end{array}$ & $\mathbf{H S D}^{* *}$ & $S D^{* 1+}$ \\
\hline $\begin{array}{c}\begin{array}{c}\text { S.Cholesterol } \\
(\mathrm{mmol} / \mathrm{L})\end{array} \\
\end{array}$ & $\begin{array}{c}4.73 \pm 0.12 \\
c \\
\end{array}$ & $\begin{array}{c}5.10 \pm 0.24 \\
\mathrm{C} \\
\end{array}$ & $\begin{array}{c}4.95 \pm 0.20 \\
C \\
\end{array}$ & $\begin{array}{c}4.97 \pm 0.25 \\
\mathrm{C} \\
\end{array}$ & $S D^{*+1}$ & $S D^{\#}$ \\
\hline $\begin{array}{l}\text { S.Triglyceride } \\
\text { (mmol/L) }\end{array}$ & $\begin{array}{c}2.23 \pm 0.10 \\
a\end{array}$ & $\begin{array}{c}2.20 \pm 0.05 \\
\mathrm{C}\end{array}$ & $\begin{array}{c}2.31 \pm 0.13 \\
\mathrm{~A}\end{array}$ & $\begin{array}{c}1.97 \pm 0.12 \\
C\end{array}$ & $\mathrm{NS}^{*}$ & $S D^{* t+}$ \\
\hline $\begin{array}{l}\text { S.VLDL } \\
(\mathrm{mmol} / \mathrm{L})\end{array}$ & $\begin{array}{c}0.92 \pm 0.03 \\
c \\
\end{array}$ & $\begin{array}{c}0.93 \pm 0.02 \\
b\end{array}$ & $\begin{array}{c}0.92 \pm 0.03 \\
C \\
\end{array}$ & $\begin{array}{c}0.91 \pm 0.03 \\
B \\
\end{array}$ & $S D^{* \ldots t}$ & HSD $^{* *}$ \\
\hline
\end{tabular}

Values are Mean \pm S.E.M

Total No. of diabetic Male Vs. Female $=87$ Vs. 78

Mean of age for diabetic men (31.35 \pm 0.66 years)

** Mean of age for diabetic female $(30.83 \pm 0.89$ years $)$

a: means non significant difference $(\mathrm{P}>0.05){ }^{*} \mathrm{~b}$ : means a highly significant difference $(\mathrm{P}<0.001)^{*}$

c: means a significant difference $(\mathrm{P}<0.05)$

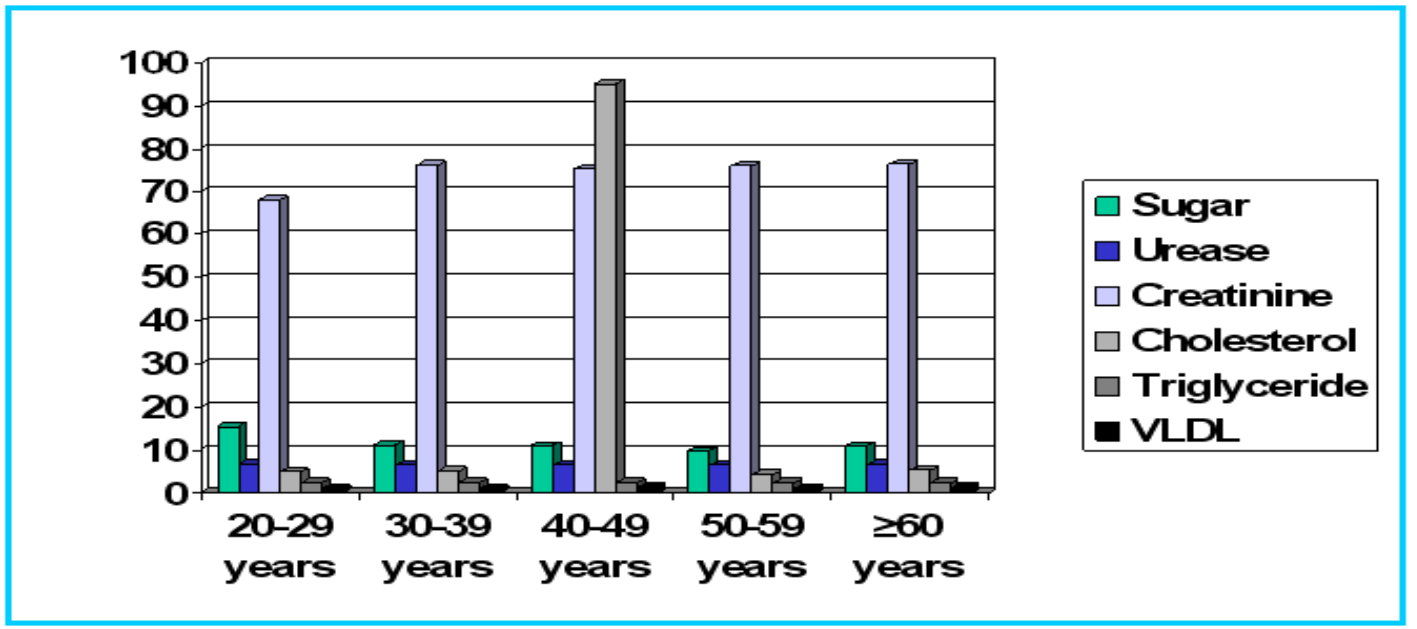

Figure (1): Blood parameters for diabetic patients classified according to male age groups

Values are Mean \pm S.E.M

Total No. of diabetic men $=87$

Mean of age for diabetic men (31.35 \pm 0.66 years 


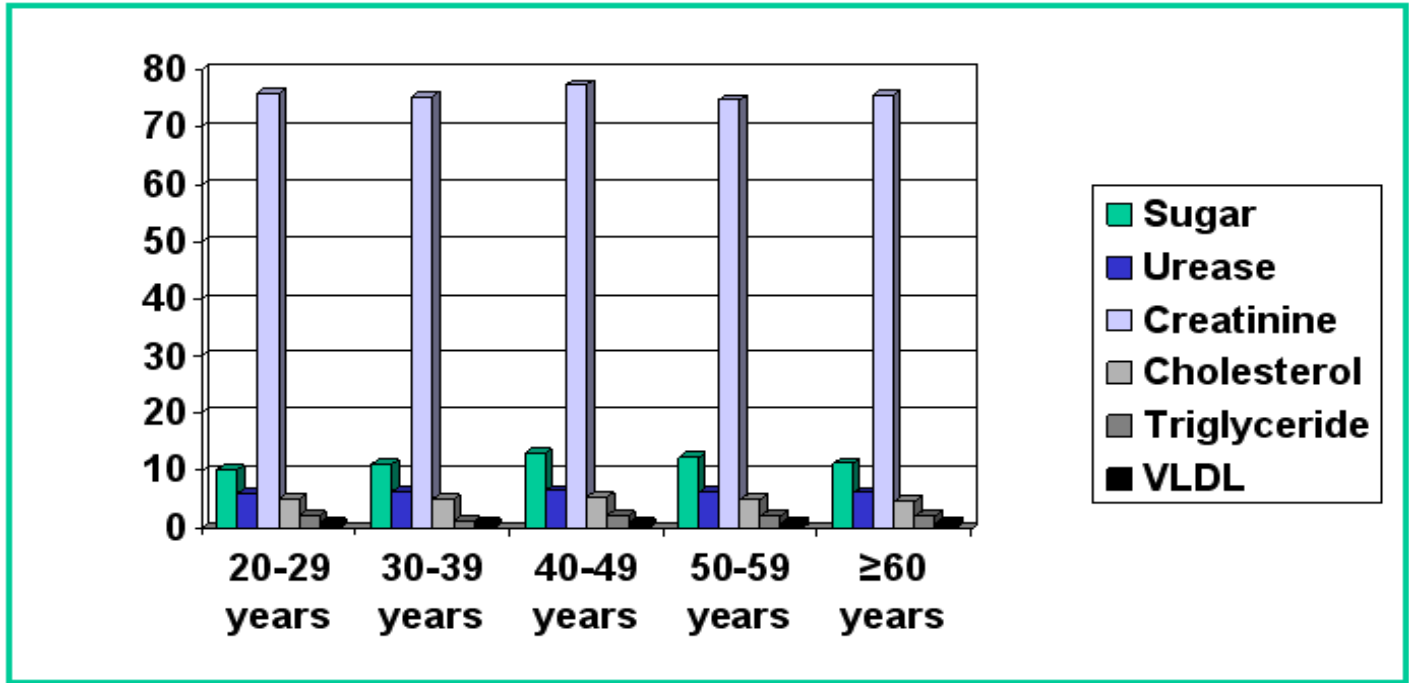

Figure (2): Blood parameters for diabetic patients classified according to female ${ }^{*}$ age groups

Values are Mean \pm S.E.M

Total No. of diabetic female $=78$

* Mean of age for diabetic female $(30.83 \pm 0.89$ years $)$

\section{$\underline{\text { Discussion }}$}

The pattern of dyslipidemia in diabetes is different from that in non diabetic population. However, this fact explains the importance of lipid and lipoprotein investigation in diabetics and suggests a different lipid lowering agents from that used in non-diabetic population; metabolic disorder of serum lipid in carbohydrate intolerance may be related to the type of diabetes (11). In addition, serum cholesterol concentrations tend to be similar to matched controls, but the multiple risk factor intervention trial (MRFIT) show that serum cholesterol remained a very important risk factor in the context of DM (12), the elevation in serum triglycerides was more evident than in serum cholesterol. As well as, it is suggested that in type II, if serum TG and VLDL levels to increase as the extent of hyperglycemic increases, one can hypothesize that increased nonenzymatic glycation of VLDL might be responsible for this increase (13). One the other hand, Glycated LDL and VLDL concentrations were significantly increased in diabetic patients compared with controls. Moreover, serum urea and serum creatinine are not sensitive indices of renal function but offer an evidence for the lack of marked renal impairment in these diabetics (14).

The very low density lipoprotein is converted into LDL by the enzyme lipoprotein lipase ,but glycated VLDL particles are not so good substrates for the enzyme lipoprotein lipase, such glycation impairs removal of it is main lipid (TG), and delays clearance of the particle as a whole. Also, glycated VLDL may be converted into LDL but because of glycated apo $E$, IDL particle remains longer in circulation (15). Additionally, the observation of LDL and VLDL particles which are thought to be analogous to LDL in diabetic plasma, support the hypothesis that, because of glycation, conversion of VLDL into LDL is slowed down and IDL particles may remain in circulation longer (16). Creatinine or urea, an indicator of liver and kidney function. Thus, indicating abnormal hepatic and renal function; possible causes of decreases in serum albumin and total protein concentration observed in the oral mucosa and interdigital regions (17). 
The number of people living with diabetes with age because it weakens the pancreatic beta cells produce less insulin and weaken their resistance and increase response vidmanl with glucose with age. Although the levels of insulin may be similar to those found in adults(17).

\section{References}

1.Kikkawa, R. (2000): Chronic complication in diabetes mellitus. Brit. J. Nutr., 48: 183-185.

2.Nacitarhan S., Ozben T., and Tuncer N. (1995): Serum and urine malonaldehyde levels in NIDDM patients with and without hyperlipidemia. Free Radical Biology and Medicine,19: 893-896

3.Tietz, N.W. (1995): Clinical Guide to Laboratory Test; $\left(3^{\text {rd }}\right)$ ed. Philadelphia, Pa. WB Saunders Company. PP. 622-629.

4.Sandek, C.D. and Eder H.A. (1979): Lipid metabolism in diabetes mellitus. Am. J. Med., 66:843952.

5.Aggrawal BBS. and Shishodia, R.S. (2006): Molecular targets of dietary agents for prevention and therapy of cancer. Biochem.Pharmacol.

6.Narayan, K.M. Boyle, J.P. Thompson, TJ. Sorensen; S.W. and Williamson, D.F. (2003): Lifetime risk for diabetes mellitus in the United States.290:1884-1890.

7. Abdul-Razzak, N.A. and Mula-Abid, W.S.(1997): Glycemic and other biochemical parameters in Iraqi diabetics .J. Fac. Med. Baghdad, 40(2):179-187.

8. American Diabetes Association (2005): Diagnosis and classification of diabetes mellitus. Diabetes Care, 28(Suppl.1); 37-43.

9. Betteridage, D.J. (2002): Diabetic dyslipidemia .Diabetes, Obesity, and metabolism 1:531-536.

10. Ludwig, D.S. and Ebbeling, C.B. (2001): Type 2 diabetes mellitus in children. 286: (12): 55-56.

11. Rustemeijer, C. Schouten, J.A. Janssen, E.N. Spooren, P.F. and Van- Doormaal, J.J. (1997): Pravastatin in diabetes associated hypercholesterolemia.Acta. diabetol. , 34: (4):294-300.

12. Stamler, J. Vaccaro; O. Neaton, J.D. and Wentworth D. (1993): Diabetes, other risk factors, and 12-yr cardiovascular mortality for men screened in the multiple risk factor intervention trial. Diabetes Care. 16: 434-444.

13. Wilson, L. (2000): Focus on diabetes mellitus http://pharminfo. Copubs /msd /diabetes HTML.

14. Yegin, A. Ozben; T. and Yegin, H. (1995): Glycation of lipoprotein and accelerated atherosclerosis in non-insulin dependent diabetes mellitus. Int. J. Clin. Lab. Res. 25:157-161.

15. El-Hazmi, MAF. Al-Swailem, A. Warsy; A.S. AL-Sudairy, F. Sulimani, R. and Al-Swailem, A. (1995): The prevalence of diabetes mellitus and impaired glucose tolerance in the population of Riyadh. Annals of Saudi Medicine. 15: 598-601.

16. ALberti, K.G. and Zimmet, P.Z.(1998): Definition, diagnosis and classification of DM and its complications. Diabetic Medicine. 15: 539-553.

17. Amos, A.F. McCarty, D.J. and Zimmet, P. (1997): The rising global burden of diabetes and its complications: Estimates and projections to the year 2010. Diabetic Med. 14 (Suppl. 5): 1-85. 


\section{تقييم تاثير العمر والجنس على بعض متغيرات بلازما الدم للمرضى المصابين بداء

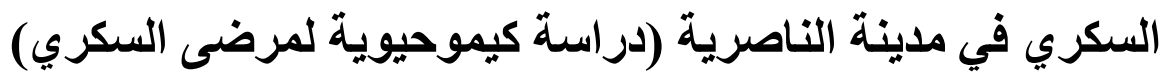 بيذاء ريحان علي الموسوي كلية العلوم- جامعة ذي قار - قسم علوم الحياة}

\section{الخلاصة}

صممت الدراسة الحالية إلى تقيبيم تاثير العمر والجنس لمرضى السكري على المتغيرات الكيموحيوية لمصـل

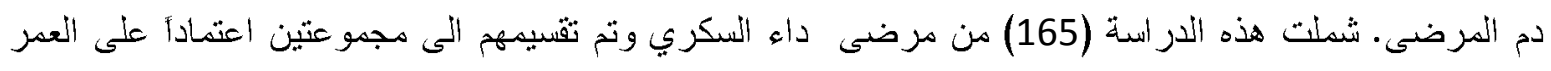

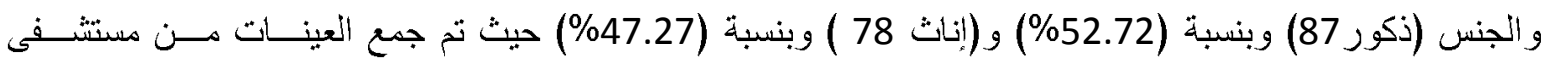

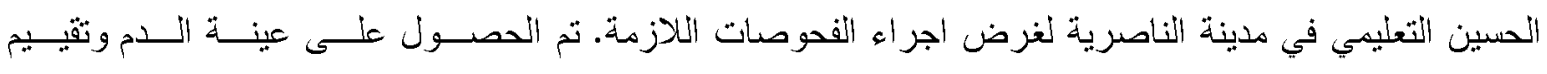

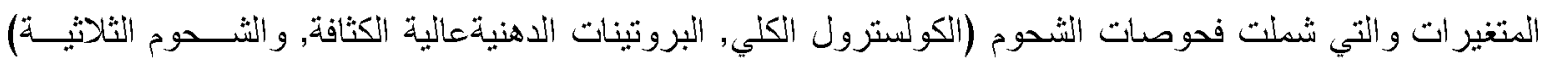

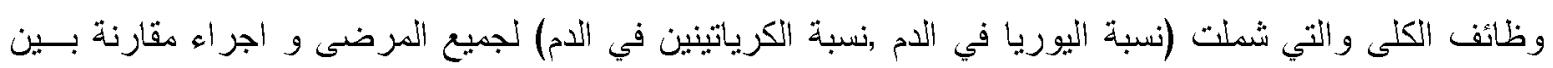
المجاميع الثلاثة.

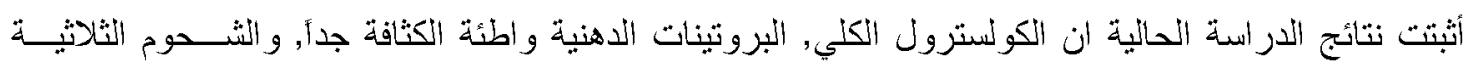

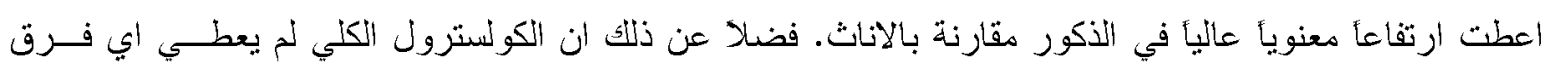

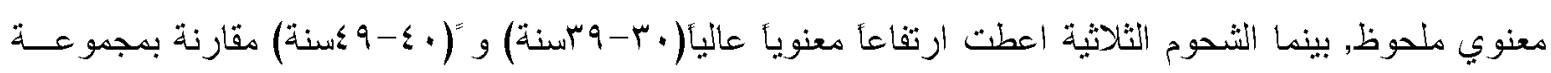

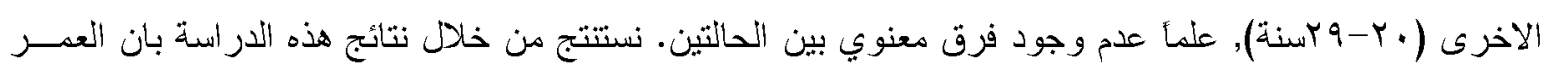
و الجنس يؤثر بشكل كبير على متغيرات تحليل الأدم وعلى كلا الجنسين. 